\title{
Spectroscopic Characterization of Chloramphenicol and Tetracycline: An Impact of Biofield Treatment
}

\author{
Mahendra Kumar Trivedi ${ }^{1}$, Shrikant Patil ${ }^{1}$, Harish Shettigar ${ }^{1}$, Khemraj Bairwa ${ }^{2}$ and Snehasis Jana ${ }^{2^{*}}$ \\ ${ }^{1}$ Trivedi Global Inc., 10624 S Eastern Avenue Suite A-969, Henderson, NV 89052, USA \\ ${ }^{2}$ Trivedi Science Research Laboratory Pvt. Ltd., Hall-A, Chinar Mega Mall, Chinar Fortune City, Hoshangabad Rd., Bhopal- 462026, Madhya Pradesh, India
}

\begin{abstract}
Objective: Chloramphenicol and tetracycline are broad-spectrum antibiotics and widely used against variety of microbial infections. Nowadays, several microbes have acquired resistance to chloramphenicol and tetracycline. The present study was aimed to evaluate the impact of biofield treatment for spectroscopic characterization of chloramphenicol and tetracycline using FT-IR and UV-Vis spectroscopy.
\end{abstract}

Methods: The study was performed in two groups (control and treatment) of each antibiotic. The control groups remained as untreated, and biofield treatment was given to treatment groups.

Results: FT-IR spectrum of treated chloramphenicol exhibited the decrease in wavenumber of $\mathrm{NO}_{2}$ from 1521 $\mathrm{cm}^{-1}$ to $1512 \mathrm{~cm}^{-1}$ and increase in wavenumber of $\mathrm{C}=\mathrm{O}$ from $1681 \mathrm{~cm}^{-1}$ to $1694 \mathrm{~cm}^{-1}$ in acylamino group. It may be due to increase of conjugation effect in $\mathrm{NO}_{2}$ group, and increased force constant of $\mathrm{C}=\mathrm{O}$ bond. As a result, stability of both $\mathrm{NO}_{2}$ and $\mathrm{C}=\mathrm{O}$ groups might be increased in treated sample as compared to control. FT-IR spectrum of treated tetracycline showed the downstream shifting of aromatic C-H stretching from $3085-3024 \mathrm{~cm}^{-1}$ to $3064-3003 \mathrm{~cm}^{-1}$ and $\mathrm{C}=\mathrm{C}$ stretching from $1648-1582 \mathrm{~cm}^{-1}$ to $1622-1569 \mathrm{~cm}^{-1}$ and up shifting of C-N stretching from $965 \mathrm{~cm}^{-1}$ to $995 \mathrm{~cm}^{-1}$. It may be due to enhanced conjugation effect in tetracycline, and increased force constant of $\mathrm{C}-\mathrm{N}\left(\mathrm{CH}_{3}\right)$ bond of tetracycline as compared to control. The results indicated the enhanced stability of treated tetracycline as compared to control. UV-Vis spectra of biofield treated chloramphenicol and tetracycline showed the similar lambda max $\left(\lambda_{\max }\right)$ to their respective control. It revealed that the chromophore groups of both antibiotics remained same as control after the biofield treatment.

Conclusion: Based on FT-IR spectroscopic data, it is speculated that due to increase in bond strength and conjugation effect after biofield treatment, the chemical stability of both the drugs might be increased as compared to control.

Keywords: Chloramphenicol; Tetracycline; Biofield treatment; Fourier transform infrared spectroscopy; Ultraviolet spectroscopy

\section{Introduction}

Chloramphenicol and tetracycline are structurally dissimilar broadspectrum antibiotics that commonly act by inhibiting the protein synthesis in microbes. These are extensively used in several microbial infections including Gram-negative, Gram-positive bacteria, chlamydiae, and rickettsiae [1-3]. Chloramphenicol reversibly binds to $50 \mathrm{~S}$ ribosomal subunit of microbes and prevents the binding of aminoacyl tRNA to 50S ribosomal subunit. Thus, it inhibits protein synthesis in bacteria, which is essential for bacterial growth [3,4]. Despite of its broad spectrum antimicrobial activities, it also has some adverse effects such as gray baby syndrome, aplastic anemia, and bone marrow depression [3,5]. Nowadays, chloramphenicol is not much effective due to development of resistance in the variety of microbes. Microbial resistances against chloramphenicol occur by several mechanisms like enzymatic (acetyltransferases and phosphotransferases) inactivation; decreasing the membrane permeability, mutation/modification in target site, and presence of efflux pumps [6]. Tetracycline exerts both bacteriostatic and bactericidal mode of action against the majority of aerobic, anaerobic, Gram-negative, and Grampositive bacteria. It binds with $30 \mathrm{~S}$ ribosomal subunit of microbes and block the binding of activated aminoacyl-tRNA to the A site of ribosome. Thus, it blocks the insertion of new amino acids to the nascent peptide chain $[2,7,8]$. Microbes acquire resistance to tetracycline by evolving the efflux pump and/or by ribosomal protection protein $[9,10]$.

Antimicrobial resistance is now conceiving as global threat; as a result need of new antimicrobial drugs is constantly increasing.
Therefore, global scientific community has attempted to discover a concept to overcome the microbial resistance i.e. reintroduction of previously used antibiotics active against multi drug resistant (MDR) bacteria. Therefore, several antimicrobial agents like chloramphenicol, tetracycline, etc are reemerging after some modifications as valuable alternatives for the treatment of difficult-to-treat microbial infections $[11,12]$.

Stability of drug is of great importance for its efficacy. In addition, drug degradation may lead to byproducts formation. Abachi et al. showed that stability of chloramphenicol was independent of $\mathrm{pH}$ between 4 to 6.2 , and it was susceptible to hydrolysis in aqueous media [13]. Lv et al. suggested that chloramphenicol was not stable in suspension form [14]. Liang et al evaluated the stability of tetracycline in methanol solution using UV-Visible spectroscopy, HPLC, and TLC methods. The report showed that tetracycline decomposed quickly

*Corresponding author: Snehasis Jana, Trivedi Science Research Laboratory Pvt. Ltd., Hall-A, Chinar Mega Mall, Chinar Fortune City, Hoshangabad Rd., Bhopal- 462026, Madhya Pradesh, India, Tel: +91-755-6660006; Email: publication@trivedisrl.com

Received June 10, 2015; Accepted July 21, 2015; Published July 24, 2015

Citation: Trivedi MK, Patil S, Shettigar H, Bairwa K, Jana S, et al. (2015) Spectroscopic Characterization of Chloramphenicol and Tetracycline: an Impact of Biofield. Pharm Anal Acta 6: 395. doi:10.4172/21532435.1000395

Copyright: (c) 2015 Trivedi MK, et al. This is an open-access article distributed under the terms of the Creative Commons Attribution License, which permits unrestricted use, distribution, and reproduction in any medium, provided the original author and source are credited. 
Citation: Trivedi MK, Patil S, Shettigar H, Bairwa K, Jana s, et al. (2015) Spectroscopic Characterization of Chloramphenicol and Tetracycline: an Impact of Biofield. Pharm Anal Acta 6: 395. doi:10.4172/21532435.1000395

Page 2 of 5

with the influence of light and atmospheric oxygen, and formed several degradation products $[15,16]$. Therefore, an alternative approach is needed that can increase the shelf life of poorly stable drug.

Recently an alternative approach, biofield treatment is recognized to change the various physical and structural properties at the atomic level of various living and non-living things. It is well established that electrical current coexist along with the magnetic field inside the human body in the form of vibratory energy particles like ions, protons, and electrons $[16,17]$. Willem Einthoven discovered an electrocardiography in 1924 to measure the human biofield. Later on, Harold Saton Burr gave the hypothesis that every dynamic process in the human body had an electrical significance. Recently, it confirmed that all the electrical process happening in human body generates magnetic field [18]. It can be observed using some medical technologies such as electrocardiography, electromyography, and electroencephalogram. The electromagnetic field of the human body is known as biofield and energy linked with this field is called biofield energy [19-21]. Thus, a human has the ability to harness the energy from environment or universe and can transmit into any living or nonliving object around this globe. The object(s) always receive the energy and responding into useful way; this process is known as biofield treatment (The Trivedi Effect ${ }^{\circledast}$ ). Mr. Trivedi's biofield treatment has altered the physicochemical and structural properties of metals and ceramics [22-24]. The growth and anatomical characteristics of medicinal plant also changed after biofield treatment [25]. The biofield treatment enhanced the yield and quality of agriculture product [26]. Moreover, the changes in antimicrobial susceptibility and biotype number of pathogenic microbe have been reported after biofield treatment [27].

Conceiving the concept of antimicrobial reuses, the present study was aimed to evaluate the impact of biofield treatment on spectral properties of two antibiotics i.e. chloramphenicol and tetracycline.

\section{Materials and Methods}

\section{Study design}

The chloramphenicol and tetracycline (Figure 1) samples were procured from Sigma-Aldrich, MA, USA; and each antibiotic was divided into two parts: control and treatment. The control samples remained as untreated, and treatment samples were handed over in sealed pack to Mr. Trivedi for biofield treatment under laboratory condition. Mr. Trivedi provided this treatment through his energy transmission process to the treatment groups without touching the objects. After that, the control and treated samples of each antibiotic were analyzed using Fourier transform infrared (FT-IR) spectroscopy and Ultraviolet-Visible (UV-Vis) spectroscopy.

\section{FT-IR spectroscopic characterization}

FT-IR spectra were recorded on Shimadzu's Fourier transform infrared spectrometer (Japan) with frequency range of 4000-500 $\mathrm{cm}^{-1}$. The FT-IR spectral analysis of chloramphenicol and tetracycline were carried out to evaluate the impact of biofield treatment at atomic level like bond strength, stability, and rigidity of chemical structure [28].

\section{$\mathrm{UV}$-Vis spectroscopic analysis}

UV-Vis spectra of chloramphenicol and tetracycline were acquired on a Shimadzu UV-2400 PC series spectrophotometer with $1 \mathrm{~cm}$ quartz cell and a slit width of $2.0 \mathrm{~nm}$. The analysis was carried out at wavelength range of 200-400 $\mathrm{nm}$. UV-Vis spectroscopic analysis was performed to evaluate the effect of biofield treatment on structural property of tested antibiotics (chloramphenicol and tetracycline) [28].

\section{Results and Discussion}

\section{FT-IR spectroscopic analysis}

FT-IR spectra of control and treated chloramphenicol are shown in Figure 2. FT-IR spectrum of control sample showed absorption peaks at $3352-3246 \mathrm{~cm}^{-1}$ that were assigned to $\mathrm{O}-\mathrm{H}$ and $\mathrm{N}-\mathrm{H}$ stretching, respectively. IR peaks at $3081 \mathrm{~cm}^{-1}$ were assigned to aromatic $\mathrm{C}-\mathrm{H}$ stretching. Vibrational peaks at 1681 and $1559 \mathrm{~cm}^{-1}$ were assigned to $\mathrm{C}=\mathrm{O}$ and $\mathrm{C}=\mathrm{C}$ stretching, respectively. Further, the $\mathrm{NO}_{2}$ and $\mathrm{C}-\mathrm{Cl}$ stretching were observed at $1521 \mathrm{~cm}^{-1}$ and $662 \mathrm{~cm}^{-1}$, respectively; and $\mathrm{N}-\mathrm{H}$ bending was appeared at $1518 \mathrm{~cm}^{-1}$. The FT-IR data of control chloramphenicol was well supported by the literature data [29].

The FT-IR spectrum of treated sample of chloramphenicol showed IR absorption peaks for $\mathrm{O}-\mathrm{H}$ and $\mathrm{N}-\mathrm{H}$ stretching at $3243 \mathrm{~cm}^{-1}$ and aromatic $\mathrm{C}-\mathrm{H}$ stretching was appeared at $3079 \mathrm{~cm}^{-1}$. The vibrational<smiles>O=C(NC(CO)C(O)c1ccc([N+](=O)[O-])cc1)C(Cl)Cl</smiles>

(a)

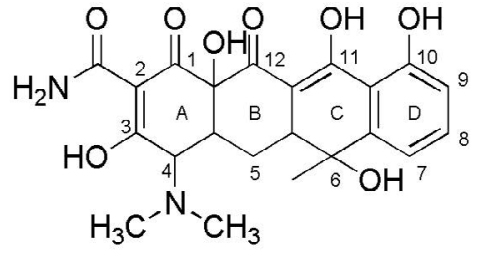

(b)
Figure 1: Chemical structure of (a) chloramphenicol and (b) tetracycline.

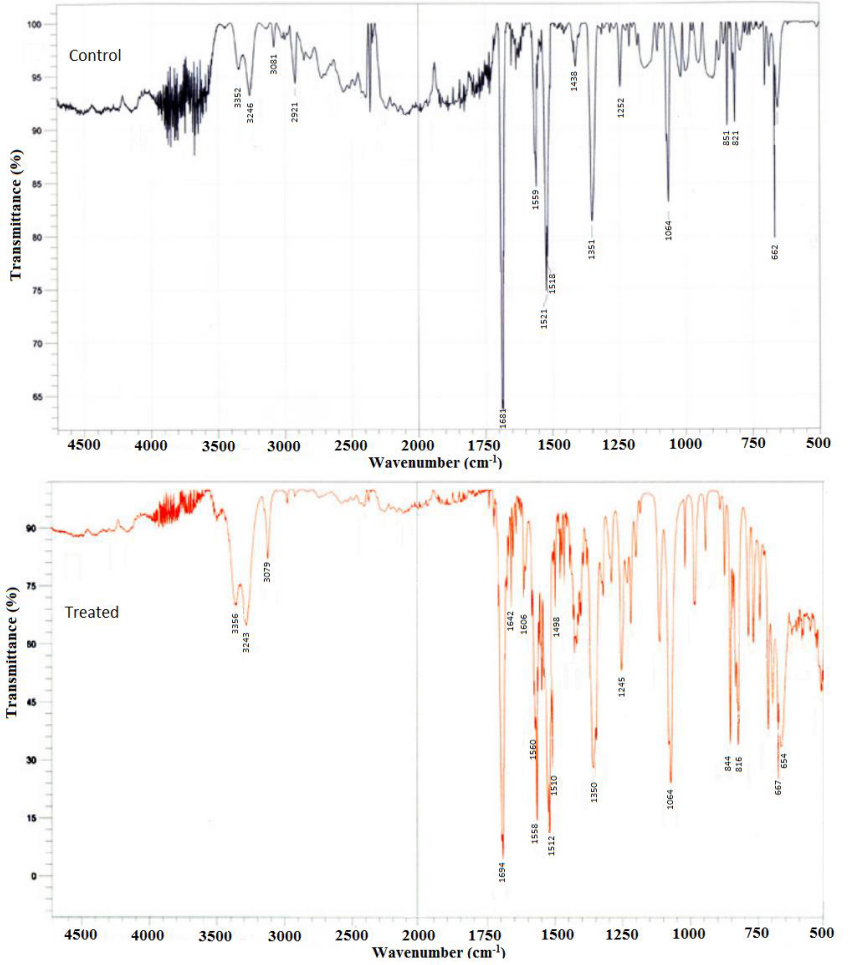

Figure 2: FT-IR spectra of chloramphenicol (control and treated). 
peak of carbonyl group $(\mathrm{C}=\mathrm{O})$ and $\mathrm{C}=\mathrm{C}$ stretching were attribute to IR peaks at 1694 and $1560 \mathrm{~cm}^{-1}$, respectively. Additionally, $\mathrm{NO}_{2}$ stretching and N-H bending peaks were appeared at 1512 and $1510 \mathrm{~cm}$ ${ }^{1}$, respectively; and C-Cl stretching was appeared at $667 \mathrm{~cm}^{-1}$.

Altogether, the result suggested that $\mathrm{C}-\mathrm{H}$ and $\mathrm{C}=\mathrm{C}$ stretching peaks of aromatic ring were observed in similar frequency region in both control and treated sample of chloramphenicol. It indicated that stability and rigidity of phenyl ring was retained in treated sample as like to control. The vibrational peaks for $\mathrm{C}=\mathrm{O}$ stretching (acylamino group) was observed towards higher frequency region i.e. from 1681 to $1694 \mathrm{~cm}^{-1}$ that may be due to an increase in force constant of $\mathrm{C}=\mathrm{O}$ group in treated chloramphenicol. Further, FT-IR spectra of treated chloramphenicol showed decrease in wavenumbers of $\mathrm{NO}_{2}$ i.e. from 1521 to $1512 \mathrm{~cm}^{-1}$. It might be occurred due to increase of conjugation effect between $\mathrm{NO}_{2}$ group and phenyl ring [30]. Force constant is directly proportional to bond strength [28]. As the force constant of $\mathrm{C}=\mathrm{O}$ was increased due to biofield treatment, the stability of acylamino moiety in treated chloramphenicol should also be increased. Additionally, the conjugation effect between $\mathrm{NO}_{2}$ group and phenyl ring may lead to increase in chemical stability of treated chloramphenicol as compared to control.

The FT-IR spectra of control and treated samples of tetracycline are shown in Figure 3. FT-IR spectrum of control sample showed the absorption peaks for N-H and O-H stretching at $3341-3329 \mathrm{~cm}^{-1}$ and aromatic C-H stretching at $3085-3024 \mathrm{~cm}^{-1}$. The vibrational peaks at $2995-2863 \mathrm{~cm}^{-1}$ and $1648-1582 \mathrm{~cm}^{-1}$ were assigned to $\mathrm{CH}_{3}$ stretching and $\mathrm{C}=\mathrm{C}$ stretching, respectively. Aromatic $\mathrm{C}-\mathrm{H}$ bending was appeared at $1458 \mathrm{~cm}^{-1}$ and $\mathrm{CH}_{3}$ bending was appeared at $1357 \mathrm{~cm}^{-1}$. The aromatic in plane and out plane deformation peaks were appeared at 1247-1000 $\mathrm{cm}^{-1}$ and $567-501 \mathrm{~cm}^{-1}$, respectively. Vibrational peak at $965 \mathrm{~cm}^{-1}$ was assigned to $\mathrm{C}-\mathrm{N}$ stretching. The FT-IR data of control sample was well supported by reported data [31].

The FT-IR spectra of treated tetracycline showed the vibrational peaks at $3342-3325 \mathrm{~cm}^{-1}$ that were attributed to $\mathrm{N}-\mathrm{H}$ and $\mathrm{O}-\mathrm{H}$ stretching. Vibrational peaks at $3064-3003 \mathrm{~cm}^{-1}$ and $2955-2835 \mathrm{~cm}^{-1}$ were assigned to $\mathrm{C}-\mathrm{H}$ and $\mathrm{CH}_{3}$ (methyl) stretching, respectively. $\mathrm{C}=\mathrm{C}$ stretching peaks were appeared at $1622-1569 \mathrm{~cm}^{-1}$. Bending vibrational peaks for $\mathrm{C}-\mathrm{H}$ and $\mathrm{CH}_{3}$ groups were appeared at 1454 and $1357 \mathrm{~cm}^{-1}$, respectively. Vibrational peaks at $1247-1000 \mathrm{~cm}^{-1}$, and $995 \mathrm{~cm}^{-1}$ were assigned to $\mathrm{C}-\mathrm{H}$ in plane deformation and $\mathrm{C}-\mathrm{N}$ stretching, respectively. The out plane ring deformation peaks were appeared $567-501 \mathrm{~cm}^{-1}$.

The FT-IR data of control and treated tetracycline showed that $\mathrm{N}-\mathrm{H}$ and $\mathrm{O}-\mathrm{H}$ stretching peaks are observed in the similar frequency region in both samples. This suggests no changes in the amide and hydroxyl group of treated tetracycline as compared to control. IR absorption peaks for $\mathrm{C}-\mathrm{H}$ (aromatic) stretching were shifted to lower frequency i.e. from $3085-3024 \mathrm{~cm}^{-1}$ to $3064-3003 \mathrm{~cm}^{-1}$ and likely the $\mathrm{CH}_{3}$ stretching was shifted to lower frequency i.e. from $2995-2863 \mathrm{~cm}^{-1}$ to $2955-2835$ $\mathrm{cm}^{-1}$. IR absorption peak for $\mathrm{C}=\mathrm{C}$ stretching was also appeared at lower frequency region i.e. form $1648-1582 \mathrm{~cm}^{-1}$ to $1622-1569 \mathrm{~cm}^{-1}$ in treated sample as compared to control. It is well known that resonance or conjugation of $\mathrm{C}=\mathrm{C}$ double bond or carbonyl group provides the more single bond character to $\mathrm{C}=\mathrm{C}$ bond that lowers the force constant of respective bond [28,30]. Further, resonance and/or conjugation effect also provide the stability to chemical compound. Therefore, it is speculated that biofield treated tetracycline might be more chemically stable due to enhanced conjugation effect in $\mathrm{C}$ and $\mathrm{D}$ ring, with respect to control. This could be correlated to enhancement in stability of treated tetracycline with respect of control. The $\mathrm{C}-\mathrm{N}$ stretching peak in treated

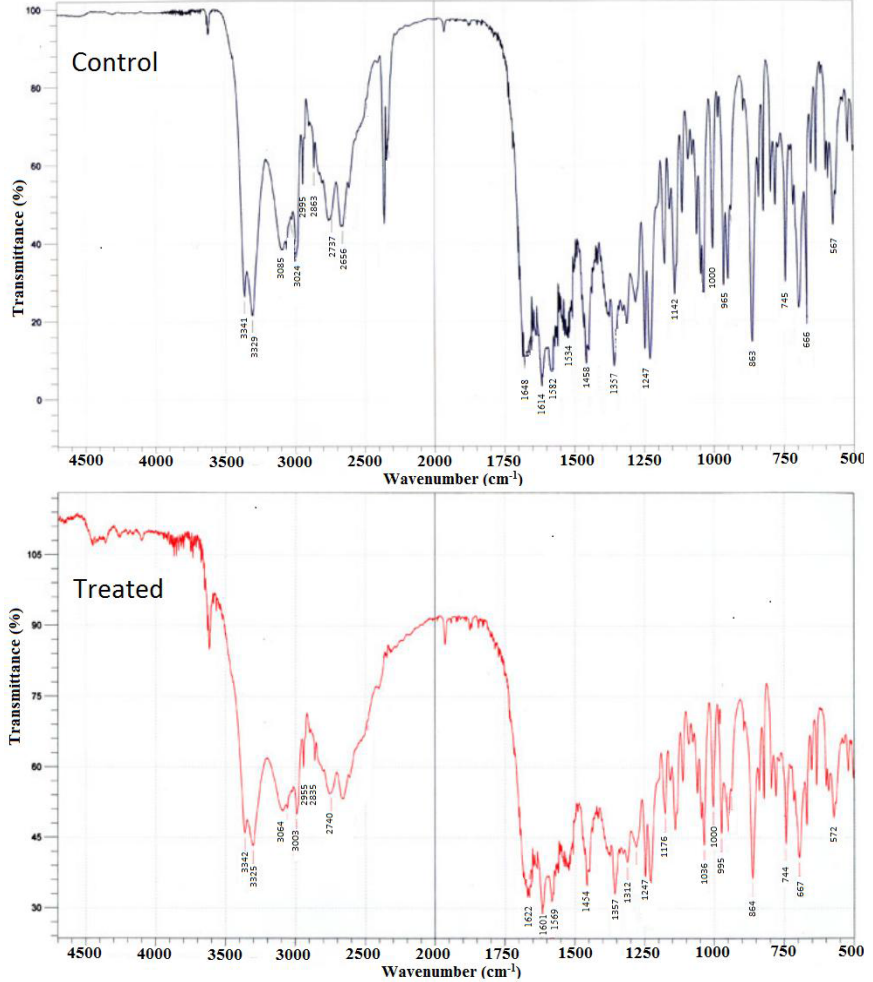

Figure 3: FT-IR spectra of tetracycline (control and treated).

tetracycline was observed at higher wavenumber than control (i.e. from 965 to $995 \mathrm{~cm}^{-1}$ ). It could be due to increased bond strength of C-N $\left(\mathrm{CH}_{3}\right)$ group that might be increased stability of treated tetracycline as compared to control.

\section{UV-Vis spectroscopy}

UV spectra of control and treated samples of chloramphenicol are shown in Figure 4. It showed no significant change in the lambda $\max \left(\lambda_{\max }\right)$ of treated sample $(273.8 \mathrm{~nm})$ as compared to control (272.2 $\mathrm{nm})$, which indicated no changes in chromophore group of treated chloramphenicol with respect to control. UV spectra of control and treated sample of tetracycline are shown in Figure 5. Both spectra showed three absorption peaks at $362.60,268.80$, and $220.60 \mathrm{~nm}$ in control sample and $362.60,268.80$, and $221 \mathrm{~nm}$ in treated sample, which indicated similar pattern of UV absorbance in both the samples. This suggested no changes in chromophore group of treated tetracycline with respect to control. Overall, the UV spectra of both the antibiotics showed no significant changes in $\lambda_{\max }$ as compared to control. Based on this, it could be concluded functional groups or their position did not altered in treated sample after biofield treatment. To the best of our knowledge, this is the first report showing an impact of biofield treatment on spectral properties (force constant, dipole moment, and bond strength) of chloramphenicol and tetracycline as compared to control.

\section{Conclusion}

Altogether, the FT-IR data showed an alteration in the wavenumber of some functional groups like $\mathrm{C}=\mathrm{O}$ and $\mathrm{NO}_{2}$ in chloramphenicol and $\mathrm{C}=\mathrm{C}$ and $\mathrm{C}-\mathrm{N}\left(\mathrm{CH}_{3}\right)$ in tetracycline with respect to control groups. This could be observed due to some alteration at the atomic level of both 
Citation: Trivedi MK, Patil S, Shettigar H, Bairwa K, Jana s, et al. (2015) Spectroscopic Characterization of Chloramphenicol and Tetracycline: an Impact of Biofield. Pharm Anal Acta 6: 395. doi:10.4172/21532435.1000395

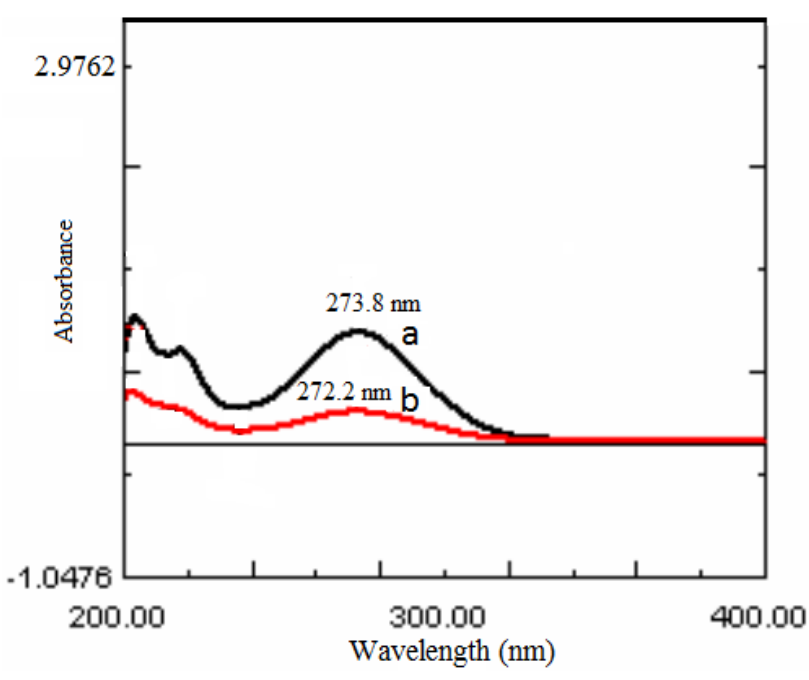

Figure 4: UV spectra of (a) control and (b) treated chloramphenicol.

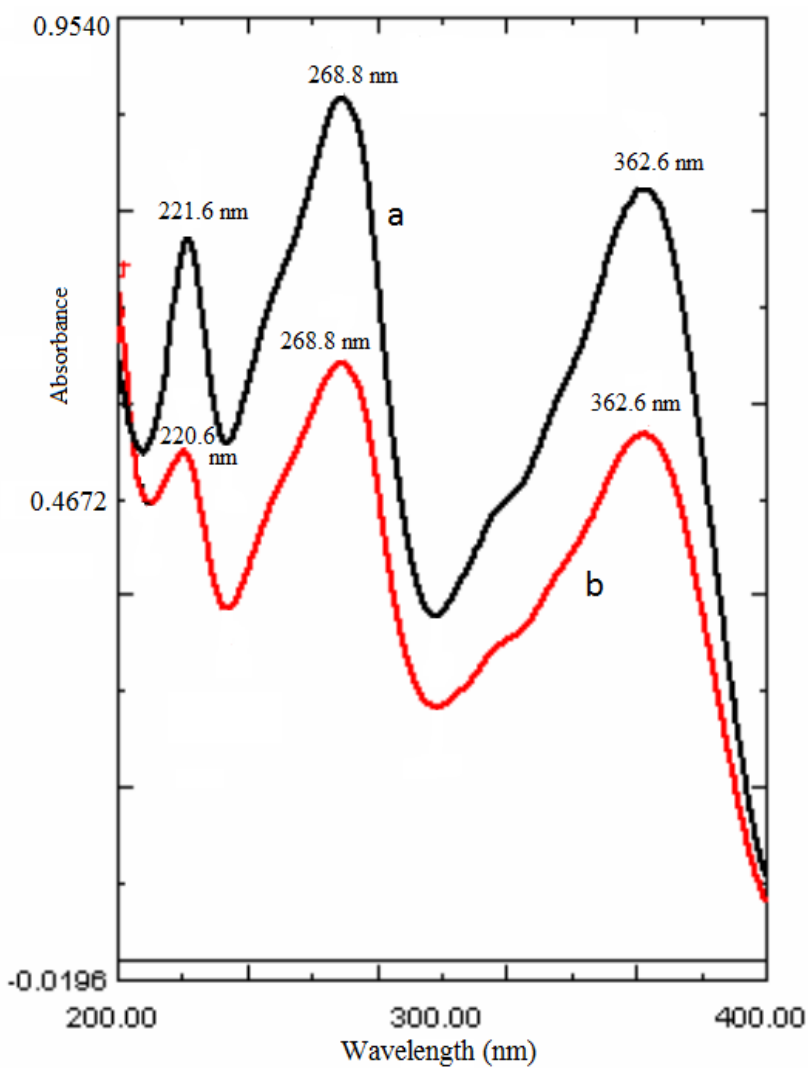

Figure 5: UV spectra of (a) control and (b) treated tetracycline.

antibiotics by the influence of biofield treatment. The results of present study suggest the impact on force constant, bond strength and dipole moment of both antibiotics that may be alter the chemical stability of biofield treatment as compared to control.

\section{Acknowledgement}

The authors would like to acknowledge the whole team of MGV Pharmacy College, Nashik for providing the instrumentalfacility. Authors would also like to thank Trivedi science, Trivedi master wellness and Trivedi testimonials for their support during the work.

\section{References}

1. Ruiz NM, Rámirez-Ronda CH (1990) Tetracyclines, macrolides, lincosamides \& chloramphenicol. Bol Asoc Med P R 82: 8-17.

2. Chopra I, Roberts M (2001) Tetracycline antibiotics: mode of action, applications, molecular biology, and epidemiology of bacterial resistance. Microbiol Mol Biol Rev 65: 232-260

3. Feder HM Jr, Osier C, Maderazo EG (1981) Chloramphenicol: A review of its use in clinical practice. Rev Infect Dis 3: 479-491.

4. Cundliffe E, McQuillen K (1967) Bacterial protein synthesis: the effects of antibiotics. J Mol Biol 30: 137-146.

5. Yunis AA (1988) Chloramphenicol: relation of structure to activity and toxicity. Annu Rev Pharmacol Toxicol 28: 83-100.

6. Fernández $\mathrm{M}$, Conde $\mathrm{S}$, de la Torre J, Molina-Santiago $\mathrm{C}$, Ramos $\mathrm{JL}$, et al (2012) Mechanisms of resistance to chloramphenicol in Pseudomonas putida KT2440. Antimicrob Agents Chemother 56: 1001-1009.

7. Zakeri B, Wright GD (2008) Chemical biology of tetracycline antibiotics Biochem Cell Biol 86: 124-136.

8. Speer BS, Shoemaker NB, Salyers AA (1992) Bacterial resistance to tetracycline: mechanisms, transfer, and clinical significance. Clin Microbiol Rev 5: 387-399.

9. Chopra I, Roberts M (2001) Tetracycline antibiotics: mode of action applications, molecular biology, and epidemiology of bacterial resistance. Microbiol Mol Biol Rev 65: 232-260

10. Connell SR, Tracz DM, Nierhaus KH, Taylor DE (2003) Ribosomal protection proteins and their mechanism of tetracycline resistance. Antimicrob Agents Chemother 47: 3675-3681.

11. Liaqat I, Sumbal F, Sabri AN (2009) Tetracycline and chloramphenicol efficiency against selected biofilm forming bacteria. Curr Microbiol 59: 212-220.

12. Cassir N, Rolain JM, Brouqui $P$ (2014) A new strategy to fight antimicrobial resistance: the revival of old antibiotics. Front Microbiol 5: 551.

13. Abachi FT, Bander F, Al- Deeb NN, Nasoh N, Gafar ZM (2010) Formulation and stability studies of chloramphenicol as ophthalmic eye drop. Tikrit J Pharm Sci 6: 70-77

14. Lv FF, Li N, Zheng LQ, Tung CH (2006) Studies on the stability of the chloramphenicol in the microemulsion free of alcohols. Eur J Pharm Biopharm 62: 288-294.

15. Liang $Y$, Denton MB, Bates RB (1998) Stability studies of tetracycline in methanol solution. J Chromatogr A 827: 45-55.

16. Planck M (1903) Treatise on Thermodynamics (3rdedn) english translated by Alexander OGG, Longmans, Green, London, UK.

17. Einstein A (1905) Does the inertia of a body depend upon its energy-content. Ann Phys 18: 639-641.

18. Maxwell JC (1865) A dynamical theory of the electromagnetic field. Phil Trans R Soc Lond 155: 459-512.

9. Rivera-Ruiz M, Cajavilca C, Varon J (2008) Einthoven's string galvanometer: the first electrocardiograph. Tex Heart Inst J 35: 174-178.

20. Burr HS (1957) Bibliography of Harold Saxton Burr. Yale J Biol Med 30: 163167.

21. Rubik B (2002) The biofield hypothesis: its biophysical basis and role in medicine. J Altern Complement Med 8: 703-717.

22. Trivedi MK, Patil S, Tallapragada RM (2012) Thought intervention through biofield changing metal powder characteristics experiments on powder characterisation at a PM Plant. Future Control Automation LNEE 173: 247-252.

23. Trivedi MK, Patil S, Tallapragada RM (2013) Effect of bio field treatment on the physical and thermal characteristics of silicon, tin and lead powders. J Material Sci Eng 2: 125.

24. Trivedi MK, Patil S, Tallapragada RM (2013) Effect of biofield treatment on the physical and thermal characteristics of vanadium pentoxide powders. J Material Sci Eng S11: 001. 
Citation: Trivedi MK, Patil S, Shettigar H, Bairwa K, Jana s, et al. (2015) Spectroscopic Characterization of Chloramphenicol and Tetracycline: an Impact of Biofield. Pharm Anal Acta 6: 395. doi:10.4172/21532435.1000395

25. Altekar N, Nayak G (2015) Effect of biofield treatment on plant growth and adaptation. J Environ Health Sci 1: 1-9.

26. Lenssen AW (2013) Biofield and fungicide seed treatment influences on soybean productivity, seed quality and weed community. Agricultural Journal 8: $138-143$.

27. Trivedi MK, Patil S (2008) Impact of an external energy on Staphylococcus epidermis [ATCC-13518] in relation to antibiotic susceptibility and biochemical reactions-an experimental study. J Accord Integr Med 4: 230-235.

28. Pavia DL, Lampman GM, Kriz GS (2001) Introduction to spectroscopy (3 ${ }^{\text {rd }}$ edn) Thomson learning, Singapore.
29. Sajan D, Sockalingum GD, Manfait M, Joe IH, Jayakumar VS (2008) NIRFT Raman, FT-IR and surface-enhanced Raman scattering spectra, with theoretical simulations on chloramphenicol. J Raman Spectros 39: 1772-1783.

30. Seshadri TR, Subba Rao NV, Subrahmanyam B (1968) Effect of conjugation and complex formation on the Raman and I.R. frequencies of the carbonyl group. Proc Indian Acad Sci Sect A 68: 314-323.

31. Gunasekaran S, Varadhan SR, Karunanidhi N (1996) Qualitative analysis on the infrared bands of tetracycline and ampicillin. Proc Indian Natl Sci Acad Part A 62: 309-316. 